\title{
KEPRIBADIAN DAN KOMUNIKASI RIA MIRANDA SEBAGAI FASHIONPRENEUR DALAM MEMBENTUK PERSONAL BRANDING
}

\author{
Rostika Yuliani Tika \\ Universitas Padjajaran, Jawa Barat \\ rostika12001@mail.unpad.ac.id
}

\begin{abstract}
Currently, there are a lot of fashionpreneurs who are currently getting into business. The fashionpreneurs compete with each other to enter the world of business both online and offline. The purpose of this study was to describe the personality and personal branding of Ria Miranda as a fashionpreuner. The research paradigm uses constructivism with the method used in this research is descriptive qualitative data collection techniques in the form of observation, literature study and online searches through social media and online media. The data analysis technique used was data reduction, data cross-checking and conclusion checking. The results showed that Ria Miranda also has personal branding in which the 8 main components include Specialization (The Law of Specialization), Leadership (The Law of Leadership). Personality (The Law of Personality), Difference (The Law of Distinctiveness), Visible (The Law of Visibility), Unity (The Law of Unity), Firmness (The Law of Persistence) and Good Name (The Law of Goodwill). Women must be able to exert influence without forgetting their identity.
\end{abstract}

Keyword : interpersonal communication; personality; personal branding

\begin{abstract}
Abstrak
Saat ini banyak sekali fashionpreneur yang saat ini sedang terjun ke arah bisnis. Adapun para fashionpreneur ini saling bersaing untuk terjun ke dunia bisnis baik secara online ataupun offline. Tujuan penelitian ini adalah untuk menggambarkan kepribadian dan personal branding yang dimiliki Ria Miranda sebagai fashionpreuner. Paradigma penelitian menggunakan konstruktivisme dengan metode yang digunakan dalam penelitian ini adalah deskriptif kualitatif dengan teknik pengumpulan data berupa observasi, studi pustaka dan penelusuran secara online melalui media sosial dan media online. Teknik analisis data yang digunakan menggunakan reduksi data, kroscek data dan pengecekan kesimpulan. Hasil penelitian menunjukkan bahwa Ria Miranda juga memiliki personal branding yang dimana ke 8 komponen utama yang meliputi Spesialisasi (The Law of Specialization), Kepemimpinan (The Law of Leadership). Kepribadian (The Law of Personality), Perbedaan (The Law of Distinctiveness), Terlihat (The Law of Visibility), Kesatuan (The Law of Unity), Keteguhan (The Law of Persistence) dan Nama Baik (The Law of Goodwill). Perempuan harus bisa memberikan pengaruh tanpa melupakan identitas mereka.
\end{abstract}

Kata Kunci : komunikasi antar pribadi; kepribadian; personal branding

\section{PENDAHULUAN}

Di era persaingan bisnis yang semakin ketat dan semakin majunya teknologi dalam mempermudah bisnis dan penjualan produk, banyak pebisnis-pebisnis yang bermunculan, tidak hanya pengusaha saja yang semakin banyak yang melakukan bisnis, tetapi saat ini banyak sekali fashionpreneur yang saat ini sedang terjun ke arah bisnis. Adapun para fashionpreneur ini saling bersaing untuk terjun ke dunia bisnis baik secara online ataupun offline dalam hal ini membuka toko secara langsung di beberapa kota dan beberapa acaraacara fashion show baik di Indonesia maupun di luar negeri agar mampu dikenal oleh banyak orang. Kehadiran Ria Miranda sebagai fashionpreneur muda ini memberikan inspirasi bagi para wanita muslimah untuk terus istiqamah dalam menggunakan hijab, adapun 
Ria Miranda ini mengalami perjuangan hidup yang cukup berat yang dimana Ria Miranda ini lahir pada tanggal 15 Juli 1985 ini meniti karier sebagai penata gaya di majalah Ex Noor dan awal kisahnya bermula ketika Ria Miranda selesai sekolah SMA di Padang, lalu Ria Miranda Hijrah ke Jakarta dengan tekad yang kuat untuk melanjutkan pendidikan sarjana di ESMOOD namun Ria merasa berat untuk melanjutkan pendidikan di Fakultas Ekonomi Universitas Andalas dengan alasan kedua orang tuanya tidak menyetujui untuk pergi merantau ke Jakarta, dan ide muncul untuk melakukan bisnis tersebut muncul dari perjalanan hidupnya yang penuh dengan perjuangan.

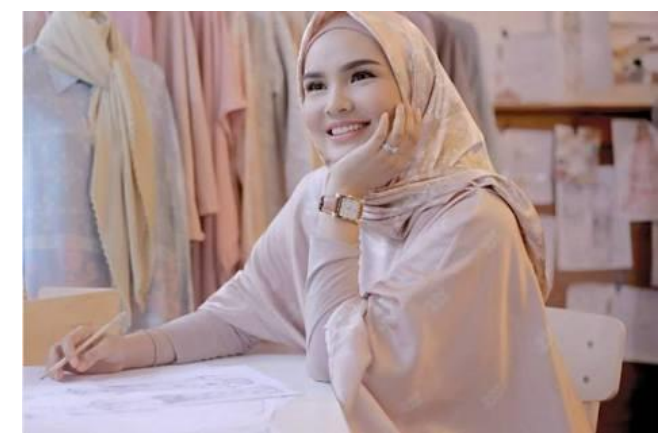

Gambar 1. Ria Miranda

sumber : riamiranda.com

Ria Miranda ini merupakan sosok yang sederhana, ramah, baik, sangat sabar dan lembut serta memiliki ciri khas tersendiri (gambar 1). Ria Miranda sendiri ketika ingin melakukan bisnis fashion muslim banyak cobaan yang cukup berat, banyak sindiransindiran bermunculan dari orang-orang mengenai fashion muslim yang diluncurkan oleh Ria Miranda di antaranya urang disukai oleh kalangan masyarakat yang menganggap bahwa nama hijab dan baju muslim rancangan Ria Miranda dianggap aneh. Namun Ria Miranda tidak pantang menyerah dengan sindiran-sindiran yang terjadi di mata masyarakat justru dia mampu memberikan prestasi yang luar biasa baik di tingkat nasional maupun di tingkat internasional diantaranya brand hijab dan baju muslimah milik Ria Miranda ini mampu acara fashion show yang dilakukan di Indonesia di antaranya adalah
Indonesia Fashion Week, Jakarta Islamic Fashion Week, Indonesia Islamic Fashion Fair, Wanita Wirausaha Mandiri, dan untuk di tingkat internasional pernah mengikuti acara London Fashion Week dan Ria Miranda sendiri khusus menyelenggarakan acara fashion shownya yang diberi nama Wardah Present Ria Miranda Trunk Show pada tahun 2014 dan pada tahun 2018 sendiri Ria Miranda akan menyelenggarakan event Fashion Show yang dinamakan Ria Miranda Twilight Spring Summer 2018.

Ria Miranda dalam menjual produk busana muslimnya adalah kalangan wanita dewasa muda. Harga produk yang dijual di dalam bisnisnya ini terdiri dari Rp 100.000-Rp 400.000 untuk kerudung dan daily outfit, Rp 600.000 - Rp 1.000.000 untuk produk signature outfit (dalam hal ini pakaian untuk acara pesta), Rp 975.000 untuk kacamata, dan Rp 425.000 untuk sepatu dengan dua warna yaitu silver dan gold (gambar 2).

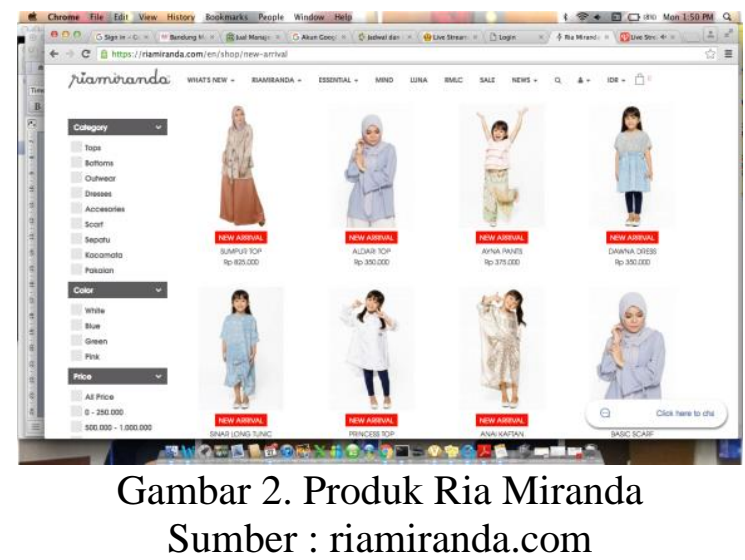

Ria Miranda berharap dengan mengeluarkan rancangan hijab dan baju muslimah ini dengan ciri khasnya yang bertemakan shabby chic dengan menggunakan warna-warna yang simple dan lembut ini mampu menarik para wanita muslimah dan memiliki dampak positif kepada masyarakat melalui desainnya yang dimana mencerminkan kepribadian yang baik.

Kepribadian dan komunikasi ini merupakan sebuah jembatan penghubung yang erat. Kepribadian ini merupakan bagian dari psikologis serta ada di dalam diri setiap 
individu, dan komunikasi itu sendiri merupakan salah satu kegiatan yang tidak pernah terpisahkan dari kehidupan manusia karena dalam kesehariannya manusia merupakan makhluk sosial yang tidak bisa lepas untuk berkomunikasi dan berinteraksi dengan orangorang yang berada di lingkungan sekitarnya. Secara Praktis, Komunikasi adalah proses menciptakan dan berbagi ide, informasi, pandangan, fakta, perasaan, di antara orangorang untuk mencapai pemahaman bersama. (Kajian, 2020).

Latar belakang Ria Miranda serta kepribadiannya yang baik membuatnya menjadi seorang fashionpreneur muda yang sukses dan mampu dikenal oleh masyarakat. Selain itu, dalam melakukan sesuatu, perlu adanya proses komunikasi yang baik sehingga pesan yang disampaikan oleh Ria Miranda baik kepada karyawannya maupun kepada masyarakat mampu berjalan dengan baik. Personal branding ini memiliki peran penting dalam keberlangsungan serta kesuksesan karier seseorang dan menjadi trend pada saat ini di berbagai kalangan masyarakat terutama dari dunia bisnis fashion muslim.

Kepribadian dan komunikasi merupakan salah satu pembentuk personal brand. Adapun personal branding ini diartikan sebagai bagaimana seseorang untuk memproduk diri mereka dengan cara membentuk kepribadian yang baik bagi diri sendiri baik secara disengaja maupun tidak disengaja, Kepribadian yang baik akan membentuk personal branding yang baik jika dilihat dari komunikasi yang efektif dan baik dengan orang lain. Sehingga penulis tertarik untuk meneliti lebih mendalam mengenai kepribadian dan komunikasi Ria Miranda dalam membentuk personal branding sebagai fashionpreneur.

Konsep teori utama yang digunakan di dalam penelitian ini adalah komunikasi antar pribadi dan personal branding. Komunikasi Antar Pribadi merupakan komunikasi yang berlangsung dalam situasi tatap muka antara dua orang atau lebih, baik secara terorganisir maupun pada kerumunan orang. Adapun berdasarkan pengertian di atas dapat disimpulkan bahwa komunikasi antar pribadi ini merupakan komunikasi yang terjadi secara dialogis, dimana saat seorang komunikator berbicara maka akan terjadi umpan balik dari komunikan sehingga terdapat interaksi. Dalam komunikasi dialogis, baik komunikator maupun komunikan, kedua-duanya aktif dalam proses pertukaran informasi yang berlangsung di dalam interaksi (Wiryanto, 2004).

Baskin dan Aronoff menjelaskan komunikasi interpersonal (antarpribadi) dengan memahami dua kata yang membentuk istilah yaitu komunikasi dan antarpribadi. Komunikasi secara sederhana bisa diartikan sebagai proses pertukaran pesan antara komunikator dan komunikan untuk mencapai tujuan tertentu. Sedangkan antarpribadi dapat diartikan sebagai berhubungan dengan atau melibatkan relasi personal atau sosial yang mengembangkan sistem-sistem ekspektasi bersama, pola-pola keterikatan emosional dan cara-cara penyesuaian sosial. Dapat dipahami komunikasi antarpribadi sebagai proses pertukaranpesan antara komunikator dan komunikan untuk mengembangkan sistem ekspektasi bersama, pola-pola keterikatan secara emosional dan cara-cara penyesuaian sosial. Komunikasi antarpribadi sebagai pertukaran pesan diantara pribadi-pribadi yang bertujuan membangun kesamaan makna. (Iriantara, 2013:8).

Adapun ciri-ciri dari efektivitas komunikasi antar pribadi di antaranya sebagai berikut : 1) Arus pesan yang cenderung dua arah; 2) Konteks komunikasinya dua arah; 3) Tingkat umpan balik yang terjadi tinggi; 4) Kemampuan mengatasi tingkat selektivitas yang tinggi; 5) Kecepatan jangkauan terhadap audience yang besar relative lambat; 6) Efek yang mungkin terjadi adalah perubahan sikap (Rogers, 2008).

Personal brand "Suatu kesan yang berkaitan dengan keahlian, perilaku maupun prestasi yang dibangun oleh seseorang baik secara sengaja maupun tidak sengaja dengan tujuan untuk menampilkan citra dirinya. 
Adapun personal brand dapat dijadikan suatu identitas yang digunakan orang lain dalam mengingat seseorang. Personal brand merupakan persepsi yang tertanam dan terpelihara di benak orang lain, yang memiliki tujuan akhir agar publik punya pandangan positif terhadapnya sehingga dapat berlanjut kepada kepercayaan dan loyalitas. Ada tiga hal mendasar yang merupakan karakteristik yang harus diperhatikan dalam merancang personal brand yang kuat, yaitu memiliki ciri khas, relevan, dan konsisten. Personal brand yang dibangun apabila memiliki kekhasan atau khusus/berbeda, relevan, dan konsisten, maka orang lain atau publik akan cepat menangkap dan memahami personal brand tersebut. (Febiansah, et.al (2020).

Personal Branding adalah kemampuan menggunakan atribut-atribut secara bebas yang menunjukkan kemampuan anda dalam mengatur harapan-harapan yang ingin orang lain terima dalam pertemuannya dengan anda. ((Mobray, 2009). Personal branding is the process by which an individual actively tries to manage others'impressions of their skills, abilities and experiences. Self-awareness and understanding one's strengths and weaknesses in order to effectively present the self is essential to building a personal brand. Students need to understand the concept of personal branding and how actions they engage today, especially in social media,can affect their future.Making students aware of the process of personal branding assists them in regulating their postings and disclosures on social media. (Johnson, 2017).

\section{Online personal}

brand

terrepresentasikan diri seseorang ketika berinteraksi dengan orang lain di dunia maya. Online personal brand yang seseorang miliki harus dapat menampilkan suatu karakter yang diinginkan serta membuat audiens ingin berinteraksi secara online dengan orang tersebut (Frischmann, 2014:4).

Online personal branding means an approach to convey great properties of an individual self in the online stage keeping in mind the end goal to separate oneself from others that will help to accomplish the expert objectives alongside social yearnings. Various studies concentrated on the significance of having a solid personal brand yet generally overlooked the method for creating it in the virtual world. (Pawar, 2016).

Dari pengertian di atas, dapat disimpulkan bahwa personal branding ini berkaitan dengan proses komunikasi tentang kepribadian, kemampuan, nilai-nilai, keahlian, perilaku, prestasi, keunikan dan bagaimana semua itu menimbulkan persepsi positif dari masyarakat yang pada akhirnya persepsi tersebut dapat menjadi suatu identitas yang digunakan oleh orang lain untuk mengingat seseorang.

Delapan hal yang merupakan konsep utama dalam membangun personal branding seseorang, di antaranya adalah: 1 . Spesialisasi (The Law of Specialization). 2. Kepemimpinan (The Law of Leadership). 3. Kepribadian (The Law of Personality). 4. Perbedaan (The Law of Distinctiveness).; 5. Terlihat (The Law of Visibility). 6. Kesatuan (The Law of Unity). Kehidupan pribadi yang berada di balik personal brand selayaknya menjadi cerminan dan citra yang diinginkan dalam personal brand; 7. Keteguhan (The Law of Persistence). 8.Nama Baik (The Law of Goodwill). (Haroen, 2014:67).

Alasan mengapa personal branding sangat efektif dan positif karena membangun diferensiasi merupakan hal yang sangat penting untuk keberhasilan personal brand, kedua Membangun positioning, ketiga Memperkuat persepsi brand yang tertanam pada publik. Brand bukan saja soal realita, tahap pertama yang harus dibangun adalah persepsi. Keempat menjadi jembatan lahirnya kepercayaan (trust). Terakhir menjadi pesan kepada publik bahwa kehadiran anda (brand) adalah solusi atas masalah maupun kebutuhan publik, sehingga pelaku personal branding dapat menggiring publik untuk bertindak mendukung dan memilih. (Haroen, 2014:18).

McNally menyebutkan brand dari diri tiap orang merupakan refleksi dari apa yang 
orang tersebut lakukan dan apa yang menjadi kepercayaan orang tersebut yang direalisasikan melalui apa yang dilakukan dan bagaimana orang itu melakukannya. Dengan adanya kontak yang berulang dengan orang lain, brand tersebut akan menjadi lebih kuat dan terbentuk dalam persepsi orang lain (McNally, David and Speak, 2004). Untuk meningkatkan pembentukan personal branding dilakukan dengan cara menampilkan minat pada foto profil dengan menggunakan objek foto dan aktivitas sesuai dengan minat tersebut, memiliki kesadaran akan citra diri individu, menampilkan secara konsisten dan berulang, menggunakan beragam media sosial sesuai dengan fungsi dan tujuan nya. (Franzia, 2018).

Merencanakan personal branding dan media sosial pada saat ini sangat penting dapat digunakan untuk membangun personal branding yang efektif yang mampu mengefisienkan usaha serta lebih mudah untuk menjangkau audiens dalam jumlah yang banyak. (Femilia Pratiwi, 2020).

Penelitian terdahulu yang dijadikan sebagai acuan dalam penelitian ini, terdapat tahapan-tahapan yang dilakukan dalam pembentukan personal branding yang dilakukan oleh Rachel Goddard Sebagai beauty travel vlogger yaitu tahap extract ialah tahap harus mengetahui jati dirinya, tahap express harus mengekspresikan dan mengkomunikasikan hal-hal yang telah dimiliki oleh Rachel Goddard, terakhir tahap extude menunjukkan konsistensi agar personal brand yang telah dibangun terus melekat pada target audiens (Tumakaka \& Dida, 2019). Penelitian selanjutnya Sebagai konten creator, Jabroo telah melakukan personal branding agar membedakan dirinya dengan konten creator lainnya, salah satunya adalah ingin menghibur netizen dan mempunyai bahasa yang khas dalam obrolannya yaitu bahasa jawa timuran (Febiansah et. al, 2020).

Makna personal branding selebgram di media sosial instagram ini menunjukan bahwa seorang selebgram yang membangun personal branding-nya melalui instagram harus lebih dulu mengenal pribadinya. Seperti apa ia ingin dinilai oleh pengguna instagram lainnya, seperti apa penilain diri terhadap pribadinya sendiri. Mengetahui dengan pasti tujuan yang ingin dicapainya dalam membentuk personal branding melalui media sosial instagram. Dan merencanakan secara pasti hal-hal yang akan menjadikannya pribadi yang berbeda dari selebgram lainnya (Audina, 2018).

Fenomena ini menarik karena fashionpreneur muslimah muda ini menjadi sosok inspiratif yang dikenal di media sosial yang menjadi sumber referensi dalam membangun bisnis. Semakin banyaknya fashionpreneur muda membuat kemampuan untuk membangun personal branding menjadi hal yang penting bagi para fashionpreneur yang lainnya agar tetap menjaga eksistensi mereka. Personal branding yang konsisten dibangun dengan kuat, pada akhirnya dapat membangun representasi perihal sosok inspiratif yang dihadirkan di dalam media sosial.

Tujuan dari penelitian ini adalah untuk menggambarkan kepribadian dan personal branding yang ditonjolkan oleh Ria Miranda melalui kompetensi, standar dan gaya yang bersangkutan.

\section{METODOLOGI}

Adapun paradigma penelitian yang digunakan di dalam penelitian ini adalah paradigma konstruktivisme. Paradigma konstruktivisme secara ontologis menyatakan bahwa realitas itu ada dalam beragam konstruksi mental yang di dasarkan kepada pengalaman sosial, bersifat lokal dan spesifik. Paradigma ini meyakini bahwa realitas bisa dipahami dalam bentuk konstruksi mental yang bermacam-macam yang didasarkan secara sosial dan pengalaman, merupakan olah cipta pikiran manusia. Paradigma ini memandang ilmu sosial sebagai analisis sistematis terhadap socially meaningful action melalui pengamatan langsung dan terperinci terhadap pelaku sosial yang bersangkutan menciptakan dan memelihara/ mengelola dunia sosial mereka (Hidayat, 2003:3)

Konstruktivisme melihat bahwa sebuah realita timbul dari proses interaksi antara 
individu dengan individu lain (masyarakat). Paradigma ini bertujuan untuk mencari pemahaman atau rekonstruksi atas suatu realita (Salim, 2006). Peneliti harus menjelaskan proses-proses pembentukan makna dan menerangkan ihwal serta bagaimana maknamakna tersebut terkandung dalam bahasa dan tindakan para aktor sosial. Upaya penyusunan interpretasi tidak lain adalah upaya melakukan pembacaan tentang makna-makna ini, mengemukakan konstruksi peneliti tentang para aktor yang ditelitinya.

Metode penelitian merupakan cara ilmiah untuk memperoleh data dengan tujuan dan kegunaan tertentu. Metode yang digunakan di dalam penelitian ini dengan menggunakan metode penelitian deskriptif kualitatif. Metode deskriptif kualitatif adalah penelitian yang menggambarkan karakteristik suatu kelompok tertentu dengan tujuan untuk membuat deskripsi, gambaran atau lukisan secara sistematis, faktual dan akurat mengenai faktafakta, sifat-sifat dan hubungan antara fenomena yang diselidiki (Bungin, 2009).

Metode deskriptif kualitatif ini mengacu pada identifikasi sifat-sifat yang membedakan atau karakteristik sekelompok manusia, benda ataupun peristiwa. Pada dasarnya, deskriptif kualitatif melibatkan proses konseptualisasi dan menghasilkan pembentukan skema-skema kualifikasi. (Creswell, 2018).

Penelitian deskriptif ditujukan untuk: (1) mengumpulkan informasi aktual secara rinci yang melukiskan gejala yang ada, (2) mengidentifikasi masalah atau memeriksa kondisi dan praktek-praktek yang berlaku, (3) membuat perbandingan atau evaluasi, (4) menentukan apa yang dilakukan orang lain dalam menghadapi masalah yang sama dan belajar dari pengalaman mereka untuk menetapkan rencana dan keputusan pada waktu yang akan datang. Penelitian kualitatif bertujuan mempertahankan bentuk dan isi perilaku manusia dan menganalisis kualitaskualitasnya, alih-alih mengubahnya menjadi entitas-entitas kuantitatif (Mulyana, 2018:150).
Instrumen penelitian yang digunakan di dalam penelitian ini adalah menggunakan observasi, studi pustaka dan penelusuran secara online. peneliti melakukan observasi dengan cara observasi non partisipan, studi pustaka dengan cara memperoleh teori-teori komunikasi dan teori-teori pendukung yang dapat memberikan penjelasan mengenai pokokpokok permasalahan yang diteliti. Dalam studi pustaka, peneliti menggunakan berbagai buku dan jurnal tentang komunikasi antar pribadi dan personal branding. Terakhir adalah penelusuran secara online dengan cara penelusuran ke akun instagram Ria Miranda sebagai data pendukung penelitian. Tata cara melakukan penelusuran data melalui media online dan media sosial seperti internet atau media jaringan lainnya yang menyediakan fasilitas online, sehingga memungkinkan peneliti dapat memanfaatkan data informasi online yang berupa data maupun informasi teori, secepat atau semudah mungkin dan dapat dipertanggungjawabkan secara akademis. Perkembangan internet yang pesat memiliki kemampuan untuk menjawab berbagai pertanyaan dan kebutuhan masyarakat melalui penelusuran informasi yang diinginkan (Bungin, 2008).

Subjek penelitian yang penulis ambil adalah Ria Miranda. Objek penelitian di dalam tulisan ini penulis akan membahas mengenai kepribadian, komunikasi dan personal branding Ria Miranda. Penelitian ini dilakukan untuk mengetahui kepribadian dan komunikasi Ria Miranda dalam membentuk personal branding.

Adapun teknik analisis data yang digunakan di dalam penelitian ini adalah reduksi data, display data, dan penarikan serta pengujian kesimpulan. Bogdan dalam (Sugiyono, 2016:244) merupakan proses mencari dan menyusun secara sistematis data yang diperoleh dari hasil wawancara, catatan lapangan dan bahan-bahan lain sehingga dapat mudah dipahami, dan temuannya dapat dinformasikan kepada orang lain.

Analisis data dapat dilakukan pada saat pengumpulan data berlangsung dan setelah 
selesai pengumpulan data. Pada saat melakukan wawancara, peneliti melakukan analisis terhadap jawaban wawancara tersebut. Jika jawaban tersebut dirasa masih kurang memuaskan, maka peneliti akan melanjutkan wawancara hingga diperoleh data yang diinginkan.

Adapun teknik analisis data yang digunakan di dalam penelitian ini adalah teknik analisis interaktif Miles dan Huberman. (Miles,M.B, Huberman, A.M, \& Saldana, 2014) merupakan upaya yang dilakukan dengan jalan bekerja dengan data, mengorganisasikan data, memilah-milahnya menjadi satuan yang dapat dikelola mensintesiskannya, mencari dan menentukan pola, menemukan apa yang penting.

Adapun di dalam penelitian ini, peneliti menggunakan teknik triangulasi untuk menguji validitas data. Alasannya adalah membandingkan informasi tentang hal yang sama yang diperoleh dari berbagai pihak, agar ada jaminan tentang tingkat kepercayaan data. Peneliti menggunakan triangulasi sumber data di dalam penelitian ini. Norman Denkin dalam (Rahardjo, 2017) triangulasi sumber data adalah menggali kebenaran informasi tertentu melalui berbagai metode dan sumber perolehan data. Misalnya, selain melalui wawancara dan observasi, peneliti bisa menggunakan observasi terlibat (participant obervation), dokumen tertulis, arsip, dokumen sejarah, catatan resmi, catatan atau tulisan pribadi dan gambar atau foto. Masing-masing cara itu akan menghasilkan bukti atau data yang berbeda, yang selanjutnya akan memberikan pandangan (insights) yang berbeda pula mengenai fenomena yang diteliti.

Selain triangulasi sumber, peneliti juga dalam menguji validitas data menggunakan triangulasi teori. Triangulasi teori merupakan Hasil akhir penelitian kualitatif berupa sebuah rumusan informasi atau thesis statement. Informasi tersebut selanjutnya dibandingkan dengan perspektif teori yang relevan untuk menghindari bias individual peneliti atas temuan atau kesimpulan yang dihasilkan.
Selain itu, triangulasi teori dapat meningkatkan kedalaman pemahaman asalkan peneliti mampu menggali pengetahuan teoretik secara mendalam atas hasil analisis data yang telah diperoleh.

Setelah melakukan triangulasi, peneliti melakukan member check atau mengecek ulang data. Member check adalah proses pengecekan data yang diperoleh peneliti kepada pemberi data.Tujuan member check adalah untuk mengetahui seberapa jauh data yang diperoleh sesuai dengan apa yang diberikan oleh pemberi data. (Sugiyono, 2008).

\section{HASIL DAN PEMBAHASAN}

Di era persaingan bisnis yang semakin banyak dan semakin meningkat, banyak fashionpreneur yang semakin marak dan adapun alasan fashionpreneur Ria Miranda melakukan personal branding adalah karena beliau ingin menyampaikan kepada masyarakat khususnya kaum wanita muslimah untuk menutup aurat dengan menggunakan hijab dan busana muslim dan dengan melalui designdesign yang Ria Miranda buat ini diharapkan mampu memberikan dampak positif kepada masyarakat yang dimana Ria Miranda ini merupakan kepribadian yang baik dan beliau merupakan bagian dari komunitas sosial.

Berdasarkan hasil analisis yang dilakukan oleh peneliti dengan cara melakukan penelusuran secara online melalui media sosial maupun di media online bahwa Ria Miranda di kenal dengan sosok orang yang baik, terbuka dan sederhana, seseorang yang open of experience atau selalu ingin mencoba hal-hal baru yang menarik, menyenangkan, dan juga menantang bagi dirinya serta dikenal sosok yang penyabar, shalehah dan selalu lembut. Ria Miranda merupakan seseorang yang terbuka dan memiliki kemauan untuk menanggapi dengan senang hati mengenai informasi dan keluhan dari masyarakat kepada dirinya mengenai produk hijab dan baju muslimah. Dari caption-caption yang dia buat di media sosial, memiliki rasa empati untuk memahami apa yang dialami oleh orang lain serta 
berorientasi dalam masalah dimana Ria Miranda memberikan informasi dan layanan mengenai keluhan tentang produk hijab dan baju muslimah serta selalu berpikir positif yang cenderung mampu bertindak berdasarkan penilaian yang baik tanpa merasa bersalah yang berlebihan, memiliki keyakinan atas kemampuannya untuk mengatasi persoalan, peka terhadap kebutuhan orang lain, pada kebiasaan sosial yang telah diterima.

Peneliti menganalisis mengenai

Personal Branding Ria Miranda berdasarkan penelusuran secara online melalui media sosial instagram milik Ria Miranda, beliau memiliki personal branding diantaranya memiliki Nilainilai baik yang menjadi prinsip atau karakter diri, memiliki kemampuan dalam mengerjakan sesuatu yang menjadi kompetensi dan passionnya, penampilan diri yang baik dengan berbagai macam gaya penampilan serta prestasi yang cukup banyak dengan mengikuti ajang fashion show di tingkat nasional maupun internasional dan menjadi Brand Ambassador Produk Wardah.

Berdasarkan hasil analisis melalui media online, Ria Miranda memiliki kepribadian yang baik dan sederhana dari sifat sosial. Kepribadian yang terbuka, ramah, memiliki kesadaran tinggi terutama dalam bertanggung jawab dan disiplin diri, kontrol diri yang baik dan keterbukaan akan mencoba halhal baru. Hal tersebut menjadikan Ria Miranda sebagai seorang pribadi yang mampu berkomunikasi baik dengan orang lain dikarenakan Ria Miranda memiliki nilai-nilai positif yang baik di dalam dirinya. Selain itu juga ciri khas yang membedakan diantara Ria Miranda dengan para fashionpreneur muda lainnya adalah dalam menjual produk busana muslim yang selalu menggunakan warna-warna simple dan shabby chic. Pemaknaan dari warnawarna yang simple dan shabby chic yang mudah ditemui pada penataan gaya shabby chic adalah sentuhan warna pastel yang lembut dan dingin, seperti merah muda, biru muda, hijau dan ungu muda. (Edupaint, 2020). Konsep Shabby Chic memiliki makna anggun, feminin, elegan, dan kasual (Summarecon Mall, 2020).
Sehingga dalam berkomunikasi Ria Miranda merupakan seseorang yang dapat berkomunikasi secara terbuka dengan orang lain karena memiliki kemauan untuk menanggapi dengan senang hati segala keluhan dan informasi yang diterima oleh masyarakat mengenai produk hijab dan baju muslimah. Dalam berkomunikasi Ria Miranda dapat memberikan hal-hal yang positif kepada masyarakat dan selalu bersikap ramah kepada setiap orang. Sikap mendukung satu sama lain dengan saling berinteraksi baik dengan suaminya yang turut membantu beliau dalam memasarkan produk secara online maupun dengan masyarakat yang ingin mengeluhkan seputar produknya sehingga hal ini menjadikan Ria Miranda sebagai seorang komunikator yang dapat mendukung orang lain dengan baik untuk mencapai tujuan-tujuan yang ingin diwujudkan bersama dengan rakyat.

Untuk memiliki keyakinan, berani dan rasa percaya diri yang tinggi. Ria Miranda harus bisa memotivasi dirinya sendiri untuk memiliki pemikiran dan citra yang positif dimana Ria Miranda ini mampu berkomunikasi baik dengan dirinya sendiri dengan cara memotivasi dirinya sendiri berdasarkan profesi yang dijalaninya pada saat ini. Serta pemikiran yang positif mengenai apa yang dilakukannya adalah untuk keluarga dan masyarakat.

Kepribadian dan komunikasi dari Ria Miranda merupakan bagian dari faktor terbentuknya personal branding pada dirinya sendiri secara alami. Citra Diri adalah gambaran diri seseorang yang tertanam dalam pikiran bawah sadar yang akan menentukan siapa dirinya. Citra Diri kita dibentuk sejak lahir dari lingkungan, pengalaman masa lalu, dan juga pengaruh orang lain. Dengan beragamnya karakter manusia dan juga budaya, citra diri seseorang tidak selalu menjadi positif. Perbedaan prinsip, keyakinan, dan juga pola pikir keluarga dan pengaruh lingkungan pergaulan bisa saja membentuk citra diri yang negatif bagi masyarakat yang berbeda prinsip dengan lingkungan kita. Ria Miranda memiliki personal branding yang dikenal sebagai sosok yang ramah, baik, sederhana, selalu sabar 
dalam menghadapi cobaan yang berat, pekerja keras, cantik dan sangat natural yang memang sudah dimiliki oleh Ria Miranda sendiri. Sedangkan dalam memasarkan produk hijab dan baju muslimahnya Ria Miranda sendiri dikenal memiliki personal branding yang dikenal ketika menjual produk-produknya sudah sesuai dengan kebutuhan wanita muslimah pada umumnya dan mempunyai ciri khas tersendiri dalam setiap produknya dan memiliki brand tersendiri yang sebelumnya dinamakan Shabby Chic dirubah menjadi Ria Miranda.

Kesuksesan Ria Miranda sebagai fashionpreneur ini tidak lepas dari dukungan suaminya yang selalu memberikan motivasi dan semangat yang tiada henti untuk terus berinovasi dalam menciptakan produkproduknya. Salah satunya yaitu, Brand identity atau usaha untuk memperkuat branding terhadap label Ria Miranda, harus mengikuti trend, kamu juga harus pintar beradapatasi dengan pelanggan. Bila dibandingkan dengan penelitian banyak persamaan dan perbedaan yang ditemukan dalam penelitian ini persamaannya adalah kebanyakan para peneliti sebelumnya lebih sering menggunakan Artis atau public figure sebagai salah satu subjek penelitian. Alasan para peneliti menggunakan artis ataupun public figure sebagai subjek penelitian karena kemajuan teknologi dalam bidang komunikasi memberikan banyak pengaruh dalam kehidupan manusia. Kemudahan yang ditawarkan oleh berbagai macam bentuk alat komunikasi modern memberikan pengaruh yang luar biasa dalam kehidupan manusia. Beberapa individu mulai memanfaatkan alat komunikasi modern untuk menunjukan eksistensinya di masyarakat luas. Salah satunya adalah dengan penggunaan media sosial instagram sebagai alat untuk membentuk atau membangun personal branding. Selain itu Fungsi Media Sosial di era digital kini dimanfaatkan dalam ranah Komunikasi Pemasaran, Khususnya di Instagram yang menjadi wadah para penggunanya memasarkan dirinya secara personal. Dalam membangun personal branding, seorang selebritis ataupun fashionpreuneur menggunakan foto maupun video untuk menggambarkan kesan yang ingin dibentuknya dalam media sosial.

Dari hasil analisis tersebut, pembahasan yang ingin dibahas dalam artikel ini adalah bahwa personal branding yang ingin ditampilkan oleh Ria Miranda selaku fashionpreneur muda ini dapat menggambarkan kepribadian dan komunikasi seorang fashionpreneur muda di media sosial saat ini, melalui pendekatan konstruktivis, peneliti mengkonstruksikan makna-makna dari setiap foto ataupun caption dari Ria Miranda sebagai sosok fashionpreneur muda yang selalu berpenampilan sederhana, dan dalam setiap produk-produk yang ditampilkan tentunya selalu up to date, sebagai seorang fashionpreneur sekaligus ibu muda yang selalu memprioritaskan keluarga dalam kehidupan sehari-hari. Dibesarkan dari keluarga yang memiliki jiwa entrepreneur membuat Ria Miranda termotivasi untuk membangun bisnis busana muslim. Berkat dukungan dari sang suami dan keluarga membuat bisnis busana muslim yang dimiliki oleh Ria Miranda semakin dikenal oleh masyarakat.

Dari hasil dan pembahasan dapat dilihat personal branding adalah tindakan dalam kehidupan orang-orang yang berperan aktif. banyak sekali manfaat yang bisa didapat orang dari menciptakan branding pada diri sendiri. Selain itu, branding memungkinkan seseorang untuk mengatur hidup mereka sendiri tanpa harus bergantung pada orang lain. Branding adalah bagian penting dari karier seseorang, adapun manfaat yang dapat diberikan personal branding kepada orang-orang, salah satunya dengan pengembangan kepercayaan, membangun koneksi, membangun kredibilitas, keuntungan dalam keyakinan, memiliki authenticity karena personal brand berasal dari hasrat, keterampilan, tujuan, dan nilai. Itu adalah hasil dari perburuan seseorang akan pemenuhan dan makna. Personal branding membantu seseorang tumbuh dari sesuatu yang dia percayai (accurate, 2020). 


\section{SIMPULAN}

Bahwa Ria Miranda memiliki kepribadian dan komunikasi yang baik. Kepribadiannya menjadikan Ria Miranda memiliki sifat sosial yang baik, ramah, sederhana, lembut, sabar dalam menghadapi cobaan yang ada dan selalu memberikan dampak yang positif bagi masyarakat. Ria Miranda memiliki kemampuan untuk berkomunikasi dimana Ria Miranda dapat dengan mudah untuk mengekspresikan dirinya, terbuka untuk menerima masukan baik dari pihak keluarga ataupun masyarakat yang ingin mengadukan atau mengeluhkan masalah produk hijab ataupun baju muslimah yang dijual oleh Ria Miranda, dan kemampuan berkomunikasi untuk saling mendukung dan saling berinteraksi satu sama lainnya. Ria Miranda juga memiliki personal branding yang dimana ke delapan komponen utama yang meliputi Spesialisasi (The Law of Specialization), Kepemimpinan (The Law of Leadership). Kepribadian (The Law of Personality), Perbedaan (The Law of Distinctiveness), Terlihat (The Law of Visibility), Kesatuan (The Law of Unity), Keteguhan (The Law of Persistence) dan Nama Baik (The Law of Goodwill). Adapun keinginan Ria Miranda sendiri adalah bahwa perempuan Indonesia berani mengungkapkan pendapat mengenai berbagai isu di masyarakat dan berani pula mengambil tindakan untuk memecahkan berbagai masalah yang ada. Tentunya tanpa melupakan peran sebagai seorang Ibu dalam keluarga. Perempuan harus bisa memberikan pengaruh tanpa melupakan identitas mereka. Saran yang diajukan dalam penelitian ini adalah perlu adanya penelitian yang lebih lanjut tentang personal branding khususnya personal branding fashionpreneur.

\section{DAFTAR PUSTAKA}

Annisa Audina, A. M. (2018). Makna Personal Branding Selebgram di Media Sosial. Prosiding Manajemen Komunikasi, 4(2), 586-592.
Bungin, B. (2008). Metode Penelitian Kualitatif. Jakarta: Prenada Media Group. Bungin, B. (2009). Penelitian Kualitatif: Komunikasi, Ekonomi, Kebijakan Publik, dan Ilmu Sosial Lainnya. Jakarta: Kencana Prenada Media.

Creswell, J. W. (2018). Research Design Qualitative, Quantitative, and Mixed Methods Approaches. United Kingdom: SAGE Publications Inc.

Dhanar Jabro Febiansah, Sudono Syueb, Siska Armawati Sufa, dan E. R. (2020). Studi Kasus Personal Branding Konten Kreator Pada Akun Twitter@Brojabrooo. WACANA: Jurnal Ilmiah Ilmu Komunikasi, $\quad$ 19(1), 92. https://doi.org/10.32509/wacana.v19i1.10 19

Femilia Pratiwi, I. (2020). Personal Branding Ria Ricis Pada Media Sosial Instagram. Jurnal Penelitian Komunikasi, 23(1), 1530.

Franzia, E. (2018). Personal Branding Melalui Media Sosial. Personal Branding Melalui Media Sosial, 15-20.

Frischmann, R. M. (2014). Online Personal Brand: Skill Set, Aura, and Identity. USA: United States of America: Create Space Independent Publishing Platform.

Haroen, D. (2014). Personal Branding: Kunci Kesuksesan Berkiprah di Dunia Politik. Jakarta: Gramedia Pustaka Utama.

Hidayat, D. N. (2003). Paradigma dan Metodologi Penelitian Sosial Empirik Klasik. Jakarta: FISIP Universitas Indonesia.

Iriantara, Y. (2013). Komunikasi Antarpribadi. Tangerang Selatan: Universitas Terbuka.

Johnson, K. M. (2017). The Importance of Personal Branding In Social Media Educating Students To Create and Manage Their Personal Brand. International Journal of Education and Social Science, 4(1), 21-27.

McNally, David and Speak, K. D. (2004). Be Your Own Brand. California: BerrettKoehler Publishers, Inc.

Miles,M.B, Huberman,A.M, \& Saldana, J. 
(2014). Qualitative Data Analysis, A Methods Sourcebook (Third). United States of America: SAGE Publications Inc.

Mobray, K. (2009). The 10Ks of Personal Branding: Create a Better You (paperback). United States of America: iUniverse.

Mulyana, D. (2018). Metode Penelitian Kualitatif: Paradigma Baru Ilmu Komunikasi Dan Ilmu Sosial Lainnya (Kedelapan). Bandung: PT. Remaja Rosdakarya.

Natasha Putri Tumakaka, Susanne Dida, F. A. A. P. (2019). Personal Branding Rachel Goddard Sebagai Beauty Travel \& Parody
Vlogger. Actadurna, 15(2), 76-97.

Rahardjo, M. (2017). Studi Kasus Dalam Penelitian Kualitatif. Malang: UIN Maulana Malik Ibrahim.

Salim, A. (2006). Teori \& Paradigma Penelitian Sosial (Kedua). Yogjakarta: Tiara Kencana.

Sugiyono. (2008). Metode Penelitian Kuantitatif Kualitatif dan $R \& D$. Bandung: Alfabeta.

Sugiyono. (2016). Metode Penelitian Kuantitatif, Kualitatif dan $R \& D(\operatorname{Ke} 24)$. Bandung: Alfabeta.

Wiryanto. (2004). Pengantar Ilmu Komunikasi. Jakarta: PT. Grasindo. 